\title{
THE INFLUENCE OF FLEXIBILITY OF WORK TO LOYALTY AND EMPLOYEE SATISFACTION MEDIATED BY WORK LIFE BALANCE TO EMPLOYEES WITH MILLENNIAL GENERATION BACKGROUND IN INDONESIA STARTUP COMPANIES
}

\author{
Muhammad Calvin CAPNARY ${ }^{1}$, Riani RACHMAWATI², Iskandar AGUNG ${ }^{3}$ \\ ${ }^{1}$ Faculty of Economic and Business, Universitas Mercu Buana, Jakarta, Indonesia \\ ${ }^{2}$ Faculty of Economic and Business, Universitas Indonesia, Depok, Indonesia \\ ${ }^{3}$ Center of Research Policy of Education and Culture, Ministry of Education and Culture, Jakarta, Indonesia \\ E-mails: ${ }^{1}$ calvincapnary@gmail.com (corresponding author); ${ }^{2}$ riani.rachmawati@gmail.com; \\ ${ }^{3}$ safrusal.1958@gmail.com
}

Received 04 September 2018; accepted 12 October 2018

\begin{abstract}
Human resource is the one of the most important elements in the company. Therefore, the company must have related strategies to retain these workers. One of them is by increasing employee loyalty and satisfaction through flexibility of work and work life balance. The strategy chosen is based on the unique characteristics of the majority of workers who entered the millennial generation. Some companies are already implementing these strategies, including startup companies. This study aims to investigate the influence of the flexibility of working on loyalty and employee satisfaction with work life balance. This research was conducted using convenience and snowball sampling technique to the 121 respondents with a millennial generation background which is worked in startup companies in Indonesia. Data obtained from respondents were processed and analyzed using structural equation modeling. The results of this study indicate that flexibility of work has significant and positive influence to loyalty and employee satisfaction. However, flexibility of work has positive and significant impact on loyalty and employee satisfaction. This research prove that work life balance have partial mediating influence in relationship between flexibility of work and loyalty. In the other hands, work life balance have no mediating a relationship between flexibility of work and the satisfaction of employee with millennial background that is worked in startup companies.
\end{abstract}

Keywords: millennial generation, startup company, flexibility of work, work life balance, loyalty, and employee satisfaction.

JEL Classification: O15.

\section{Introduction}

Human resource is an important element in the company. All processes in the company or organization will not be able to run properly if the organization does not have or having lack of human resources in carrying out a process that is in the organization. Therefore, the company must have a strategy related to gain and maintain the availability of human resources within the organization. One of the strategies undertaken by the organization to retain these workers is to provide flexibility of work or better known as the Flexible Work Arrangements (FWA). Flexibility of work is given as a form of variation when working, thus making the workers to do not feel bored. According Possenried and Plantenga (2011), flexible work arrangements (FWA) has three general categories, namely flexibility in scheduling (scheduling), flexibility in the location (telehomeworking), and flexibility in time (part-time).

According to Shagvaliyeva and Yazdanifard (2014), one of the flexibility of the work that is as flexible working hours can be summarized as the ability of members of the organization to control the duration of their working hours based on the location of work (outside the workplace) and

\footnotetext{
Copyright $\odot 2018$ The Authors. Published by VGTU Press.

This is an Open Access article distributed under the terms of the Creative Commons Attribution License (http://creativecommons.org/licenses/by/4.0/), which permits unrestricted use, distribution, and reproduction in any medium, provided the original author and source are credited..
} 
the ability to meet work schedules provided by the organization. Provision of work flexibility has the advantage of the organization and members of the organization. For organizations, the provision of labor flexibility can attract, acquire and retain members of the organization with good quality in their organizations (Casper and Harris 2008).

The implementation of flexible working hours can increase the sense of responsibility and work life balance of the member in organizations (Hofacker and Konigm 2013). Flexible working hours also has a good impact to mental health of members of the organization by reducing their stress levels (Lewis and Humbert 2010). Kreitner and Kinicki (2012) argues that the mental health of members of the organization have a positive effect on job satisfaction of the organization's members.

Implementation of flexibility of work is one of the company's strategies to maintain the members of their organizations to provide a balance between life forms and their work, or better known as work life balance. Clark (2000) defines work life balance as a satisfaction and function at work and at home, with minimal conflict role. With the work life balance, members of an organization can have an individual's ability to meet commitments to work and family, as well as the responsibilities and activities of the other non-work (Parkes and Langford 2008). Granting Work life balance proved to have an impact and positive influence on the low willingness of members of the organization to come out of the organization, increased performance, and job satisfaction (Cegarra-Leiva et al. 2012, Nelson et al. 1990, Scandura and Lankau 1997).

Many factors that influenced why the company choosing to apply the work life balance, one of them is if the organization is dominated by the generation $\mathrm{Y}$ or commonly called the millennial generation. According Dannar (2013), Generation Y or commonly called the millennial generation is the generation which is born from 1980 to 2000. Dannar assume that this is the generation that will dominating in the world of work from 2002, and will continue to grow until 2022 (Hershatter and Epstein, 2010). Application of work life balance is considered important, especially if it is given to members of the organization with the background of the millennial generation who have paid more attention to the balance in work and life (Zemke et al. 2000)

Redpepper on their research in 2015 find interesting facts and data about the millennial generation. They are found that $90 \%$ of millennials will move to the brand and the organization that is able to realize their ideals. $64 \%$ of millennials choose a job according to their passion in the sense that they tend to choose a job with a salary that is small compared to the drudgery. Their research also found that $45 \%$ of the millenial generation spent more than one hour to shop online and spend between 20-21 hours of their time per day for access to social media.
Based of those reasons are jobs that do not match their interests, the environment that were not appropriate, or a disharmonious relationship with the boss. This is reinforced by the opinions of Seppanen and Gualtieri (2012) from the National Chamber Foundation, which says that the millennial generation works best when given clear guidance, in the frequency and get quick feedback from colleagues and superiors, in a context, clarity, and independence. They prefer to work in teams and make a group decision. They did not leave room for ambiguity and slow process. They appreciate the trust and transparency.

Many corporate organizations are already applying the flexibility of working to build a work life balance in their organizations, including startup companies. Startup companies according to Blank (2013) is a temporary organization designed to search for their business model of recurring business and scalable by using technology as a business platform. Ries (2011) says that the startup company is designed to deal with situations of extreme uncertainty. It can be said that the company is a startup company that was looking for a hypothesis in his business. Therefore, it needs people who are full of creativity to support innovation so that companies can find hypothesis of business.

One example is a startup company that is engaged in the sector of travel and tourism in South Jakarta. That startup company with the largest data storage in the sectors of travel and tourism in Indonesia are in the interview that researchers done with their human resource manager in 2016 said that they had the flexibility of working to support work life balance in their company. Work life balance is applied in the form of working hours and workplace flexibility and communications that promote the role of technologies such as email and social media.

Work flexibility and work life balance was implemented with consideration of the age of members of their organization who have on average the youngest 19 and the oldest aged 36 years or can be said to be dominated by the millennial generation. The average age of those making the company took the decision to apply the work life balance and flexibility work in their organizations. Implementation of work life balance in the company not only in the form working of the hours flexibility, but also their workplace flexibility.

Examples of a company above confirmed that several startup companies in Indonesia already applied the flexibility of working in order to support the work life balance of their employees. With the implementation of the work flexibility, the company expects the balance between work and life of the workers they met so that the members of the organization are satisfied in their jobs and feel loyal to the company where they work. Employee satisfaction and loyalty is an important factor to maintain the workers within the organization or company. However, until now 
there has been no research to prove that the flexibility of labor supplied by the company of their workers especially in companies dominated by the millennial generation has an influence on the loyalty and satisfaction of these workers

\section{Literature review}

\section{Definition and characteristics of millennial generation}

Millennials or commonly as known as a generation $\mathrm{Y}$ is the generation which is born from 1980 to 2000 (Dannar 2013). The millennial generation will dominate in the world of work starting in 2002 and will continue to grow until 2022 later (Hershatter and Epstein 2010). This generation is very focused on balance in their lives. They want shared and participation in decision-making, and they have high expectations of themselves and their employers and educators. They also want more closeness to superiors and coworkers (Martin and Tulgan 2001). According to Loudon and Bitta (1993), psychographically millennial generation has the characteristics of socially driven or have a high awareness of their social status, diversly motivated or have the character of an adventure, socioeconomically introverted or willing to spend money to meet the pleasure and sport oriented or want to spend a fortune to Sports. Cheung (in Weingarten 2008) said that the millennial generation has a character full of confidence, prosecutors and impatient, have low loyalty, social nature, has a lot of talent, and respect for education.

\section{Startup company}

Startup companies according to Blank (2013) is a temporary organization designed to search for a business model of recurring business and scalable by using technology as a business platform. Ries (2011) says that the startup company is designed to deal with situations of extreme uncertainty. Ries also argued that the company has the characteristics startup full of activities related to building institutions, such as hiring employees who are creative, coordinate their activities, and create a corporate culture that delivers results. The characteristics that make a startup company is generally considered an employer with a relatively young age. It was taken on the grounds that the employee at a young age to have creativity better than the employee who entered middle age or old ladder. The creativity is the cornerstone to support the manufacture of innovative products or services to consumers. Therefore, according to Ries (2011) to support the creativity and innovation of startup companies apply different working environments with enterprise in general. The working environment is applied in the form of a work environment that is more relaxed and fun accompanied with supporting facilities for recreation and fun.

\section{Flexibility of work}

Flexibility of work not only include hours of work or the workplace, but also includes the division of labor, time off work, part-time, and the period of employment. Flexibility of work commonly called the flexible working arrangement (FWA) (Shagvaliyeva and Yazdanifard 2014). According to Atkinson and Hall (2011), work flexibility is defined as the ability of workers to control the duration of their good work from any location based on the schedule that has been given. Deshwal (2015) says that FWA has a different shape on the business hours usually. The difference is the hours and working time in the sense that workers can do their work on time whenever and wherever they want. Deshwal (2015) also argues that the flexibility of labor is a form of planning of the organization against their members without intending to reduce the working hours of a member. According to Albion (2004) work flexibility has four categories, namely that allow variations in working hours without loss of salary including flexitime, flexible shift arrangements and telecommuting, the settings in the form of reduced hours and wages, paid and leave rights related to the family, and provisions ad hoc to unforeseen circumstances.

\section{Loyalty}

According to Iqbal et al. (2015), employee loyalty can be defined that the workers have a commitment for the success of their organization and believe that work within the organization is the best option. According to Nasiri et al. (2015), loyalty can be defined as the feeling would have on the organization. With loyalty, members of the organization have a sense of responsibility to the organization that has contributed to participate in building and developing their organization. P. A. Adler and P. Adler (1988) said that loyalty to the organization can develop a dependency on the organization's member organization, a strong sense of membership, shared responsibility, confidence in the organization, alignment with voluntary, and the tendency to comply with existing regulations on the organization. Mehta et al. (2010) says there are two kinds of loyalty, ie internal loyalty which includes feels concerned about the affiliation and commitment to the organization, and external loyalty or loyalty provided by the organization through programs and regulations.

\section{Job satisfaction}

Kreitner and Kinicki (2012) defined job satisfaction as the attitude of the workers to their jobs. The attitude represents positive and negative behaviors (Greenberg and Baron, 2003). In line with Brief (1998) which is defines job satisfaction as a pleasant emotional statements resulting from a person's work assessment, effective reaction to one's work 
and one's attitude towards work. That is two definitions showing a positive attitude. However, there is inherent emotional and psychological relationship between employees where he works (Locke 1969). Bowling and Hammond (2008) says there are two dimensions in job satisfaction, the satisfaction at work in general and on the job this time.

\section{Work life balance}

Ransome (2007) defines the work life balance as payment for the work and life covers everything outside of formal employment that is usually used in the connotation of the realm of family or home life. Clark (2000) describes the work life balance as satisfaction and function well in the workplace or at home. In line with Ransome (2007) and Clark (2000), Parkes and Langford (2008) says that work life balance is an individual's ability to meet commitments to work and family, as well as the responsibilities and activities of the other non-job. Hudson (2005) also defines the work life balance as a satisfactory level of involvement or 'match' between a dual role in a person's life. The dual role includes a role in the organization and the role of family members. In accordance with Thornthwaite (2004), which is implies work life balance as the combination of work and life of members of the organization. Greenhaus et al. (2003) defines the work life balance as the extent to which individuals are equally involved in-and equally satisfied with the work and role in the family. Researchers divided the three dimensions in the work life balance, the time balance or equilibrium in time, involvement balance or equilibrium in the psychological effort, and satisfaction balance or balance refers satisfaction expressed in the work and roles in the family.

\section{Research methodology}

The first stage that researchers did in this study was to determine the variables, dimensions, models, and theories used in the questionnaire. After that, the researcher chose the respondents to be used in this study. Next the researchers conducted a pilot test by giving questionnaires to 5 respondents outside the target respondents. A pilot test is conducted to see whether the language used in the questionnaire is understandable. The pilot test results showed that the five people outside the target respondents could work on the questionnaire easily. The pilot test results from the questionnaire indicate that the language used by researchers in the questionnaire as a research test tool is easy to understand and not confusing.

The next step in this research is pretest. Pretest is done by distributing questionnaires to 30 people with millennial backgrounds who work at Indonesian startup companies. Pretest is done to determine the feasibility of the questionnaire which will be used as a test tool to be tested to respondents in the field. The feasibility of the questionnaire is measured by looking at the value of the validity and reliability of the data collected. Processing from the results of the pretest was carried out using the SPSS 23.0 for Windows program to measure the level of validity and reliability of the questionnaire. The level of validity and reliability of the measuring instrument used in the study was obtained from the results of the data processing.

The distribution of questionnaires in this study used convenience and snowball sampling techniques. The distribution of questionnaires was carried out by selecting several relatives in accordance with the criteria in this study, namely employees who worked in startup companies, including in the millennial generation (born from 1980-2000), and implemented work flexibility in their jobs. Then the researchers asked for help from some of these people to help distribute the questionnaire to their colleagues who had the same criteria as them. The distribution of the questionnaire was carried out until the respondent's target set by the researcher was reached, which is at least 115 people. From the distribution of the questionnaire, data collected from 121 total respondents. This data collected by questionnaire is then used by researchers in the processing and analysis.

\section{Research hypotheses}

The research model below (Figure 1) describes a summary of the variables and hypotheses used in the study:

It can be seen in the research model above, the model illustrates that work flexibility is thought to have an influence on loyalty and job satisfaction is mediated by work life balance of workers with millennial generation background working in startup companies in Indonesia.

From the research model above this paper consist of two hypotheses, they are:

H1: Flexibility of work affect the loyalty of workers with a background in the millennial generation mediated by work life balance in Indonesia startup companies.

$\mathrm{H} 2$ : Flexibility of work effect on worker satisfaction with the background of the millennial generation mediated by work life balance in Indonesia startup companies.

Loyalty and employee satisfaction is an independent variable. While the work is a dependent variable flexibility

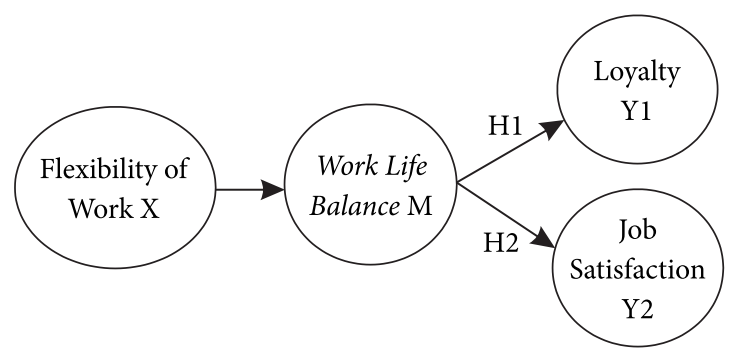

Figure 1. Research model 
and work life balance as a mediating variable. Flexibility of work in this study refers to four categories of flexibility of work of Albion (2004), which consists of flexible arrangements that are regularly available to staff and which allow variations in working hours or conditions without losing salaries, the usual arrangements involved are reduced hours (and as consequently reducing salaries), flexibility of paid work and unpaid leave entitlements related to family, and work flexibility which consists of ad hoc provisions that people can access to meet unforeseen circumstances. As a measuring tool, in this study researchers used a Flexible Work Options Questionnaire (FWOQ) from Albion (2004) as a measuring tool.

Work-life Balance in this study refers to the definition described by Greenhaus et al. (2003) namely the extent to which an individual is equally involved in and equally satisfied in work and family roles. The measuring instrument used in this study refers to Ozdevecioğlu and Aktas (2007) who in their research adapted three indicators from Greenhaus, Collins, and Shaw as a test tool, namely time balance, involvement balance, and satisfaction balance.

Whereas as a measure of employee loyalty, this study uses the loyalty theory of Mehta et al. (2010) which divides loyalty into two dimensions, namely internal loyalty and external loyalty. The measuring instrument used for worker loyalty refers to the measuring instrument developed in the research conducted by Martensen and Grønholdt (2006) and Antonova (2016).

To measure employee satisfaction, this study uses Bowling and Hammond (2008) which identified two dimensions of job satisfaction in the Michigan Organizational Assessment Questionnaire, namely general work (job in general) and current work (work in present job). The Michigan Organizational Assessment Questionnaire was chosen by researchers with the consideration of being proven to be valid and reliable as a tool to measure affirmative and emotional job satisfaction in the research questionnaire, the researcher also gave open questions to ask opinions of research samples regarding the implementation of work flexibility on loyalty, employee satisfaction, and their work life balance as a reinforcement of data arguments.

\section{Population and sample}

This study using convenience and snowball sampling. This technique chosen by reason of researchers is found difficulties to find companies that are willing to become a sample and respondent in the research. From seven companies, only one company that receiving a researchers because the data confidential reasons. In this research, the number of samples needed based on the theory of Hair et al. (2006) that is five times the total indicator (item). From 23 indicators that multiplied by five, so it needs minimum of 115 respondents in this research. The criteria for the sample of respondents is the millennial generation of men and women who were born from 1990 to 2000 who worked at a startup company in Indonesia which runs work flexibility. Researchers obtained a total of 121 respondents.

\section{Types of data}

Data collection of this study consisted of two types, namely primary data and secondary data. Primary data obtained from questionnaires. The company's secondary data and field survey which includes data such as companies websites, corporate data, and the study of literature sourced from books, the Internet, corporate pages, journals, and other data related with research. The analysis of data in this research using quantitative methods by used a Likert scale of 5 that was processed using SPSS 23.0 and Lisrel 8.8 Version.

The SPSS 23.0 program is used to test the validity and reliability of the pretest instrument before it is applied in actual field research using a factor analysis and looking at the Keyser-Meyer-Olkin (KMO) value, measure of adequacy, and the loading factor indicated by the component value in the analysis output. Measuring instruments in the study are considered valid if the KMO and MSA values have values greater than 0.5 (Malhotra 2010) and the loading factor is more than 0.5. In addition, the significance value of the Bartlett's Test of Spehricity must be less than 0.05 . Reliability test can be said good if the value of Cronbach's alpha greater than 0.6 (Malhotra 2010). Data that processed shows that all instruments are valid and reliable.

The lisrel 8.8 program is used to test the Goodness of Fit using four criteria, namely: (1) Chi-square $\left(\mathrm{X}^{2}\right)$, if $\mathrm{X}^{2}=\mathrm{O}$ means that the model has a perfect fit, the smaller the Chisquare $\left(\mathrm{X}^{2}\right)$ the better; (2) GFI (Goodness of Fit Indeces), if GFI $\geq 0.09$ the model is said to be fit; (3) P-value (probability value), if $\mathrm{P}$-value is 0.05 , the model is said to be fit; and (4) RMSEA (Root Mean Square Error of Approximation), if RMSEA is 0.08 the model is said to be fit with the data. In this study the results of testing the model get, the value of ChiSquare $=277.16 ; \mathrm{df}=156 ; \mathrm{P}$-value $=0.00000$; and RMSEA $($ Root Mean Square Error of Approximation $)=0.08$. This result indicates a saturated or perfect model. The model is fit with the data, so that the path that is formed (modified) meets the conformity requirements of the model.

\section{Results}

\section{Respondent description}

The object of this study is the millennial generation who worked at a startup company in Indonesia. The millennial generation is the generation born from 1990 to 2000 . As a startup company refers to the opinion of the Rama Mamuaya, a founder of DailySocial.id which is said there are three groups of startup companies in Indonesia, which is the creator of game startup, startup educational 
applications, and startup e-commerce and information. In general, a startup company is a company that is still looking for its business model and using technology as a business platform (Blank 2013).

Collected 121 questionnaires to analyzed in this study. Based on questionnaires, obtained a majority of $64.47 \%$ respondent that worked in e-commerce and information startup company with the male gender of $63.70 \%$ with a marital status is not married by $58.68 \%$, aged $21-25$ years amounted to $56.20 \%$ with the highest education level S1 or bachelor of $77.70 \%$. the majority of respondents worked between 1-2 years with the amount of $56.20 \%$ with a majority have a monthly income of Rp. 3,100,000 - Rp. 5,000,000 per month. In this research the majority of respondents still have position as a staff with a percentage of $75.20 \%$.

\section{Goodness of fit model}

Before the test the hypothesis needs to be tested fit model. Standard grades Goodness of Fit Indices (GOFI) for the models listed in the Table 1 below:

Table 1. Goodness of Fit testing

\begin{tabular}{|c|c|c|c|}
\hline $\begin{array}{c}\text { Goodness of } \\
\text { Fit }\end{array}$ & $\begin{array}{l}\text { Standard of } \\
\text { Value }\end{array}$ & Result & $\begin{array}{l}\text { Goodness of Fit } \\
\text { Conclusion }\end{array}$ \\
\hline P-Value & $\geq 0.05$ & 0.00000 & Not Good \\
\hline RMSEA & $\leq 0.08$ & 0.08 & Good \\
\hline NFI & $\geq 0.09$ & 0.92 & Good \\
\hline NNFI & $\geq 0.09$ & 0.94 & Good \\
\hline CFI & $\geq 0.09$ & 0.95 & Good \\
\hline IFI & $\geq 0.09$ & 0.96 & Good \\
\hline RFI & $\geq 0.09$ & 0.90 & Good \\
\hline GFI & $\geq 0.08$ & 0.81 & Good \\
\hline $\begin{array}{l}\text { Normed } \\
\text { Chi-Square } \\
\text { (Chi-Square } \\
\text { devided } d f \leq 2 \text { ) }\end{array}$ & $\begin{array}{c}277.16 / 156= \\
1.78\end{array}$ & & Good \\
\hline
\end{tabular}

\section{Hypothesis testing result}

Hypothesis testing is done by using path analysis. Influence among variables will be assessed significant and the hypothesis is accepted if the value of $t$ is greater than $t$ table is
1.96 (Wijanto 2015). So here are the results of path analysis that illustrates the significance of the influence between each variable.

From the results that obtained by researcher shows that $t$ value of the flexibility of work showed the value of 4.41 on loyalty and 3.88 on job satisfaction. The value is greater than the absolute value of 1.96 , which means work flexibility has significant influence and positive impact on loyalty and job satisfaction. Thus it can be concluded that the first and second hypothesis is accepted.

Based on the result of indirect effects in the table above, a score of loyalty mediated work flexibility work life balance shows the value of 2.28. The value that qualified must be more than equal to 1.96 so that it can be said that the work life balance has a partial mediating of labour flexibility to the loyalty of workers with a background in the millennial generation startup companies in Indonesia. Different results obtained in mediating effect of work life balance against the effects of work flexibility on worker satisfaction. In the above table values obtained 1.42. Values are means ineligible from mediation are more equal to 1.96 so that it can be said that the work life balance do not have the flexibility of working toward mediation between worker job satisfactions with the background of the millennial generation in Indonesia startup company.

\section{Discussion}

Based on the data obtained through questionnaires that researchers do and the processing of the data, it was found that the flexibility of work have significant and positive effect on loyalty. It can be seen from the value of $t$ that indicates the value of 4.41 that qualifies greater significance is equal to 1.96 . The greater work flexibility provided by organizations to their members, the greater the loyalty of members to the organization.

The results obtained by the researchers in line with the results of research conducted by some previous researchers. Shagvaliyeva and Yazdanifard (2014) in their study showed that work flexibility provided by organizations to their members has an influence on the loyalty of members of the organization. ACAS (2015) in his research also showed that labor flexibility has an influence on the loyalty

Table 2. Hypothesis testing result (resource: processed by researchers)

\begin{tabular}{|l|c|l|c|c|}
\hline \multicolumn{1}{|c|}{ Research Hypotheses } & t-value & $\begin{array}{l}\text { Significant Testing } \\
\text { Result }\end{array}$ & $\begin{array}{c}\text { Factor } \\
\text { Loading }\end{array}$ \\
\hline $\begin{array}{l}\text { Flexibility of work affect the loyalty of workers with a } \\
\text { background in the millennial generation mediated by work life } \\
\text { balance in Indonesia startup companies. }\end{array}$ & 2.28 & Significant & H1 Accepted & 0.08 \\
\hline $\begin{array}{l}\text { Flexibility of work effect on worker satisfaction with the } \\
\text { background of the millennial generation mediated by work life } \\
\text { balance in Indonesia startup companies }\end{array}$ & 1.42 & Not Significant & H2 Not Accepted & 0.05 \\
\hline
\end{tabular}




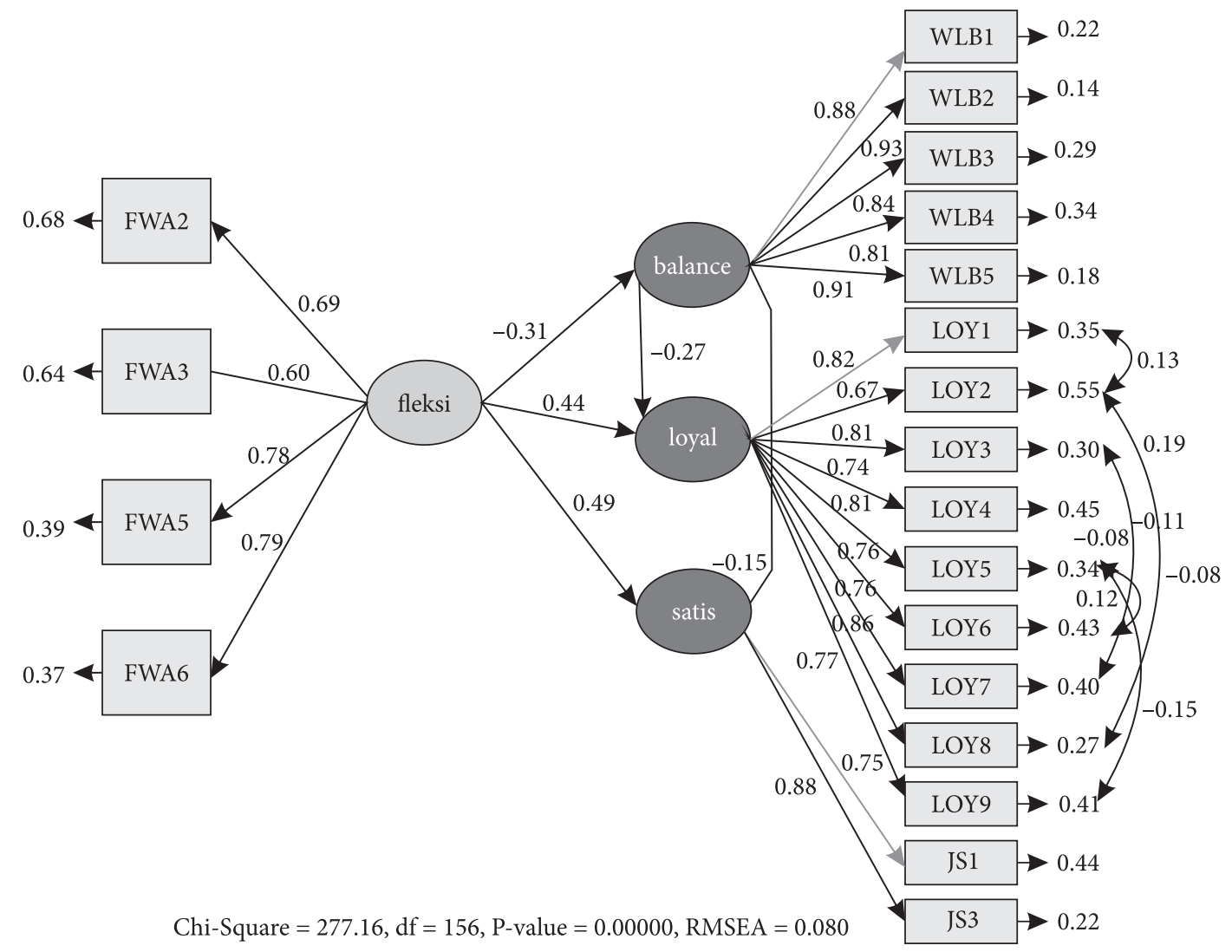

Figure 2. Standardized solution testing results

of members of the organization. In line with research conducted by Shagvaliyeva and Yazdanifard (2014) and ACAS (2015), Altindag and Siller (2014) also suggests that flexible working has a positive and significant impact on the loyalty of members of the organization.

To see the extent to which labor flexibility and worker satisfaction affects loyalty of members of the organization with a background in the millennial generation startup companies in Indonesia, investigators conducted an analysis to see the value of factor loading of test results standardized solution. In the standardized test solution is obtained as follows in Figure 2.

From Figure 2, a score factor loading of variable flexibility of work represented by flexi and loyalty that represented by a loyal showing results at the lowest loading factor item second question, namely "I often miss staff meetings, training, and other important matters". These results suggest that although the members of the organization to get the flexibility of working from the organization, they are allegedly still did not miss staff meetings, training and other important matters at the office. So that members of the organization continue to feel proud to be part of the company. The results can be seen from the highest factor loading value loyalty variables represented by loyal item eighth question, such as "I am proud to be part of this company".
From the test results of the indirect effect of MSG to ETA value $t$ obtained, work life balance has a mediating effect partially to the influence of the flexibility of work to loyalty. Results are means that can flexibility of work influencing loyalty directly or through the work life balance of workers with a background in the millennial generation in Indonesia startup companies. Researchers get results according to research conducted by Shagvaliyeva and Yazdanifard (2014) which says that the flexibility of working with significant influence on loyalty through the work life balance.

Researchers believe the results obtained are affected by survey respondents were used in the study, namely the millennial generation which is born in 1980 to 2000. The millennial generation by Zemke et al. (2000) have unique characteristics that are very focused on balance in life, including in the balance work and family life. When the flexibility of the labor supplied is able to create a balance in work and life in the family to the worker, the worker with a background in the millennial generation will have a loyalty to the company where they work. In an interview that researchers do with some human resource manager of a startup company in Indonesia found that several startup companies in Indonesia have the flexibility of working at their company. Flexibility of work have to balance between work and life of the workers of the millennial generation in 
the startup company. The results of this study found that the flexibility of the labor supplied has an influence on work life balance of workers against the background of the millennial generation in startup companies Indonesia and work life balance that can also affect the loyalty of workers with a background in the millennial generation working in startup companies Indonesia.

From Figure 2, we can see the factor loading value of flexibility of work variables that represented by flexi on loyalty that represented by loyal showing results loading factor low on an item the second question, namely "I often miss staff meetings, training, and other important matters". These results suggest that although the members of the organization to get the flexibility of working from the organization, they are allegedly still did not miss staff meetings, training and other important matters at the office. So that members of the organization continue to feel proud to be part of the company. The results can be seen from the highest factor loading value loyalty variables represented by loyal item eighth question, ie "I am proud to be part of this company".

Based on these results, it can be seen that although millennial get the flexibility of work from the company, but the company continues to provide information and carry out good communication with these workers so that workers who carry out work flexibility to stay informed about staff meetings, training and other critical notifications. Communication is an important thing in the application of the flexibility of working in the company. As the opinion expressed by ACAS in 2015 which says that communication is one of the challenges in working flexibility. Lockwood (2003), his work also has a similar opinion. Lockwood believes that communication is key to the success of the work life balance within the company or organization. Therefore, with good communication patterns work flexibility provided by a startup company in Indonesia to workers with a background in the millennial generation is able to produce work life balance of these workers. When the millennial generation workers find work life balance, then their loyalty will increase.

Good communication is one of the most important things for the workers of the millennial generation. According to Martin and Tulgan (2001) has the character of the millennial generation that wants more closeness to the boss and co-workers. When disturbed communication patterns, proximity member organization whose background millennials with superiors and co-workers became distracted. Communication is an important factor in the millennial generation due to the millennial generation has a character dependent on others as well as technology (Lancaster and Stillman 2002). In addition, according to Cheung millennial generation (in Weingarten 2008) has the characteristics of a social nature that uphold relationships with their colleagues.
Startup companies are company that uses technology as their platform, including to communicate with their workers. With the technology, the communication between workers and between employers to workers can be helped. By using the role of technology, although workers millennials run work flexibility they can still be able to communicate with co-workers or their bosses who were at the office so that the closeness between workers and workers with fixed employer can be established. The closeness that can create a sense of loyalty of workers with a background in the millennial generation in Indonesia startup company.

Other results showed that researchers do conclude that work flexibility provided by the organization has significant influence and positive impact on worker satisfaction with a background in the millennial generation startup companies in Indonesia. The results can be seen from the value of $t$ that indicates the value of 3.88 . The value of eligible greater significance is equal to 1.96 . Tests that researchers do indicate that there is an influence of the flexibility of working on worker satisfaction with the background of the millennial generation in a startup company in Indonesia in accordance with previous studies conducted by Altindag and Siller (2014) and Thomson (2008) which showed that there is positive and significant of workplace flexibility on worker satisfaction. In line with research conducted by McNall et al. (2010) and DeCaro et al. (2010) also suggests that flexible working has a positive impact on employee satisfaction.

Although the hypothesis test result shows that work flexibility provided by the organization to have a positive and significant results to job satisfaction, but different results obtained when the influence of the flexibility of working on job satisfaction is mediated by a work life balance. The test results indirect effect MSG to ETA that researchers do get results that work life balance do not have an influence on the effect of mediation between labor flexibility and worker satisfaction. The results show that there are other factors that affect worker satisfaction with the background of the millennial generation in the company startup Indonesia besides work life balance in the delivery of work flexibility by Indonesian startup company.

Researchers speculate that increased working hours due to work flexibility into the factors affecting the level of satisfaction of these workers. The assumption is strengthened by the researchers open answers given to respondents. The number 22 male respondents said that "labor flexibility actually makes life does not balance. because they have always standby to work". In line with the answers of male respondents number 13 which says "When the flexible working hours, it is sacrificed is the work life balance" and the answers of male respondents number 44 which says "Flexibility of work sometimes even make no balance between work and family because we must standby in everytime, even in the weekend". Allegations of researchers also confirmed the 
results of Mansoor et al. (2011) and Musthapa and Ghee (2013) which states that the stress of work and excessive working hours negatively affect employee job satisfaction.

The increased working hours makes the members of the organization with a background in startup companies millennials Indonesia has struggled to maintain a balance between work and life. Can be seen from the value of factor loading in Figure 2, the value of the item in question from the second variable work life balance that reads "I find it difficult to maintain a balance between work and my life" scored the highest loading factor is 0.93 .

Characters from the millennial generation that researchers use as respondents had a stake in the outcome that researchers get in the study. According to Zemke et al. (2000), the millennial generation has a character very focused on balance in their lives, including the balance between work and family. Therefore, when the millennial generation feel the work and role in the family is not balanced, it will affect their job satisfaction.

\section{Conclusions}

This research shows that flexibility of work has positive and significant impact on loyalty and employee satisfaction with the background of the millennial generation in Indonesia startup companies. In this study also showed that work life balance has partially mediating effect to the loyalty of workers with a background in the millennial generation startup companies in Indonesia. Different results obtained on the effect of mediation on work life balance in the relationship between labor flexibility on worker satisfaction. Results showed that the work life balance does not have a mediating effect on the relationship between work flexibility on worker satisfaction with the background of the millennial generation in Indonesia startup companies.

Based on the results of this study, it can be said that the flexibility of work provided by startup companies in Indonesia has an influence on the loyalty and satisfaction of workers with the millennial generation background especially if associated with the characteristics of the millennial generation. However, there are several things that need to be improved by the company. Therefore, researchers want to provide some managerial implications that can be applied to startup companies in Indonesia.

Flexibility of work has a positive and significant influence on the loyalty of members of organizations with millennial backgrounds at Indonesian startup companies. And also the mediating effect of work life balance to relationship between flexibility of work and loyalty. These results mean that giving the flexibility of a startup company to workers who have a millennial background can produce work life balance for workers. The work life balance will affect and impact on loyalty in workers. Therefore, the greater the flexibility of work provided by the company to workers with a millennial generation background, the greater the work life balance and loyalty of the workers will be.

With good communication patterns, the closeness between workers who run the flexibility of working with colleagues or superiors who are in the office is maintained so that it can create a sense of loyalty to workers with millennial backgrounds at Indonesian startup companies. Especially if it is associated with the characteristics of the millennial generation who want more closeness with their colleagues and superiors and are social.

In this study also obtained results that the flexibility of work given by startup companies to workers with millennial backgrounds has an impact on their job satisfaction. Therefore, the greater the flexibility of work provided by startup companies to their workers with a millennial generation background, it will have an impact on the greater satisfaction of these workers.

The results of the tests conducted by the researchers in this study get results that work life balance does not have a mediating effect on the relationship between work flexibility and worker satisfaction. These results mean that work flexibility affects satisfaction significantly not because of the work life balance felt by workers with millennial backgrounds at Indonesian startup companies.

In this study, work flexibility has an influence on the satisfaction of workers with millennial generations who work in startup companies in Indonesia. However, different results are obtained when linked to the work life balance that the worker feels. Researchers suspect that irregular and unclear working hours make millennials feel that work and life with their families are not balanced so that it will affect the decline in the level of satisfaction of their workers. Therefore, companies or organizations are encouraged to implement and make regulations more about the time of the members of the organization with their families. This is related to the characteristics of the millennial generation who focus on the balance of their lives, including the balance between work and time with family.

\section{References}

ACAS (2015) Flexible working and work life balance http://m. acas.org.uk/media/pdf/3/1/Flexible_working_and_work_life_ balance_Nov.pdf

Adler PA, Adler P (1988) Intense loyalty in organizations: a case study of college athletics. Administrative Science Quarterly 33: 401-417. https://doi.org/10.2307/2392716

Albion MJ (2004) A measure of attitudes towards flexible working options. Australian Journal of Management 29 (2): 275-294. https://doi.org/10.1177/031289620402900207

Altindag E, Siller F (2014) Effects of flexible working method on employee performance: an empirical study in Turkey. Business and Economic Journal 5. https://doi.org/10.4172/21516219.1000104 
Antonova E (2016) Occupational stress, job satisfaction, and employee loyalty in hospitality industry: a comparative case Study of Two Hotels in Russia. Master Thesis submitted in fulfillment of the Degree Master of Science in International Tourism.

Atkinson C, Hall L (2011) Flexible working and happiness in the NHS. Employee Relations 33 (2): 88-105.

Blank S (2013) Why the lean start-up changes everything https:// hbr.org/2013/05/why-the-lean-start-up-changes-everything

Bowling NA, Hammond GD (2008) A meta-analytic examination of the construct validity of the Michigan organizational assessment questionnaire sob satisfaction subscale. Journal of Vocational Behavior 73: 63-77. https://doi.org/10.1016/j. jvb.2008.01.004

Brief AP (1998) Attitudes in and around organizations. Thousand Oaks, CA: Sage.

Casper WJ, Harris CM (2008) Work-life benefits and organizational attachment: self-interest utility and signaling theory models. Journal of Vocational Behavior 72: 95-109. https:// doi.org/10.1016/j.jvb.2007.10.015

Cegarra-Leiva D, Sánchez-Vidal ME, Cegarra-Navarro JG (2012) Understanding the link between work life balance practices and organizational outcomes in SMEs. Personnel Review 41 (3): 359-379. https://doi.org/10.1108/00483481211212986

Clark SC (2000) Work/family border theory: a new theory of work/family balance. Human Relations 53 (6): 747-770. https://doi.org/10.1177/0018726700536001

Dannar PR (2013) Millennials: what they offer our organizations and how leaders can make sure they deliver. The Journal of Values-Based Leadership 6 (1): 1-12.

Deshwal P (2015) Impact of flexible working arrangements in the MNCs of Delhi. International Journal of Applied Research 1 (13): 810-814.

Greenberg J, Baron R (2003) Behavior in organizations (understanding and managing the human side of work) (8th ed). Prentice Hall.

Greenhaus JH, Collins KM, Shaw JD (2003) The relation between work-family balance and quality of life. Journal of Vocational Behavior 63: 510-531. https://doi.org/10.1016/S00018791(02)00042-8

Hair Jr JF, Black WC, Babin BJ, Anderson RE, Tatham RL (2006) Multivariate data analysis (6th ed). Upper Saddle River, NJ: Pearson Prentice Hall.

Hershatter A, Epstein M (2010) Millennials and the world of work: an organization and management perspective. Journal of $\mathrm{Bu}-$ siness Psychology 25 (13): 211-223. https://doi.org/10.1007/ s10869-010-9160-y

Hofacker D, Konig, S (2013) Flexibility and work-life conflict in times of crisis: a gender perspective. International Journal of Sociology and Social Policy 33 (9-10): 613-635.

Hudson (2005) The case for work life balance: closing the gap between policy and practice, 20:20 Series. Hudson Global Resources.

Iqbal A, Tufail MS, Lodhi RN (2015) Employee loyalty and organizational commitment in Pakistani organizations. Global Journal of Human Resource Management 3 (1): 1-11.

Kreitner R, Kinicki A (2012) Organizational behavioral (10th ed). Boston: McGraw-Hill.
Lancaster LC, Stillman D (2002) When generations collide. Who they are. Why they clash. How to solve the generational puzzle at work. New York: Collins Business.

Lewis S, Humbert AL (2010) Work-life balance, flexible working policies and the gendered organization. equality, diversity and inclusion. International Journal 29 (3): 239-254. https://doi. org/10.1108/02610151011028840

Loudon DL, Bitta AJD (1993) Consumer behavior, concepts and applications (4th ed). Singapore: McGraw-Hill.

Locke EA (1969) What is job satisfaction? Organizational Behavior and Human Performance 4 (4): 309-336 https://doi. org/10.1016/0030-5073(69)90013-0

Lockwood R (2003) Work life balance: challenge and solutions. Society For Human Resource Management 48 (6).

Mansoor M, Fida S, Nasir S, Ahmad Z (2011) The impact of job stress on employee job satifaction a study on telecomunication sector of Pakistan. Journal of Bussiness Studies Quarterly 1 (3): 50-56.

Martensen A, Grønholdt L (2006) Internal marketing: a study of employee loyalty, its determinants and consequences. Innovative Marketing 2: 92-116.

Martin CA, Tulgan B (2001) Managing Generation Y. Amherst: HRD Press.

Malhotra NK (2010) Marketing research: an applied approach. New York: Pearson Education.

Mehta S, Singh T, Bhakar SS, Sinha B (2010) Employee loyalty towards organization-a study of academician. International Journal of Bussiness Management and Economic Research 1 (1): 98-108.

Mustapha N, Ghee WY (2013) Examining faculty workload as a single antecedent of job satisfaction among higher public education staff in kelantan. Business and Management Horizons 1 (1): 10. https://doi.org/10.5296/bmh.v1i1.3205

Nasiri S, Najafbagy R, Nasiripour AA (2015) The impact of employee loyalty on the success of commercial organizations: a case study on the dealerships of heavy equipment in Iran. Journal of Human Resource Management 3 (3): 27-32. https:// doi.org/10.11648/j.jhrm.20150303.12

Nelson DL, Quick JC, Hitt MA, Moesel D (1990) Politics, lack of career progress, and work/home conflict: stress and strain for working women. Sex Roles 23 (3/4): 169-185.

Ozdevecioğlu M, Aktaş A (2007) Commitment to dedication, professional career and organizational impact on general life satisfaction of infidelity: the role of work-family conflict. Erciyes University. Journal of Faculty of Economics and Administrative Sciences 28 (January-June): 1-20.

Parkes LP, Langford PH (2008) Work-life balance or work-life alignment? A test of the importance of work-life balance for employee engagement and intention to stay in organizations. Journal of Management \& Organization 14 (3): 67-284.

Possenried D, Plantenga J (2011) Access to flexible work arrangements, working-time fit and job satisfaction. Tjalling $\mathrm{C}$. Koopmans Research Institute, Utrecht.

Ransome P (2007) Conceptualizing boundaries between 'life' and 'work'. International Journal of Human Resources Management 18 (3): 374-386. https://doi.org/10.1080/ 09585190601167425 
Ries E (2011) The lean startup: how constant innovation creates radically successful businesses. New York: Random House, inc.

Scandura TA, Lankau MJ (1997) Relationships of gender, family responsibility and flexible work hours to organizational commitment and job satisfaction. Journal of Organizational Behavior 18: 377-391. https://doi.org/10.1002/(SICI)10991379(199707)18:4<377::AID-JOB807>3.0.CO;2-1

Seppanen S, Gualtieri W (2012) The millennial generation: research review. USA: National Chamber Foundation.

Shagvaliyeva S, Yazdanifard R (2014) Impact on flexible working hours on work-life balance. American Journal of Industrial and Business Management, 20-23. https://doi.org/10.4236/ ajibm.2014.41004

Thomson P (2008) The business benefits of flexible workin. Strategic HR Review 7 (2): 17-22. https://doi.org/10.1108/ 14754390810853129
Thornthwaite L (2004) Working time and work-family balance: a review of employees' preferences. Asia Pacific Journal of Human Resources 42: 166-184. https://doi.org/10.1177/ 1038411104045360

Weingarten R (2008) Four generations, one workplace: A Gen $\mathrm{X}-\mathrm{Y}$ staff nurse's view of team building in the emergency department. Journal of Emergency Nursing 10: 1-4.

Wijanto (2015) Metode Penelitian menggunakan Structural Equation Modeling dengan LISREL 9. Depok: LIP-FEUI.

Zemke R, Raines C, Filipczak B (2000) Generations at work: managing the clash of veterans, boomers, Xers and nexters in your workplace (2nd ed). New York: American Management Association. 